\title{
Does Impact Of Organizational Climate And Motivation On Organizational Commitment Moderate By Job Satisfaction? A Case in Broadcasting Industry
}

\author{
Ryan Alfonso Marpaung, RinaAnindita \\ University of Esa Unggul
}

\begin{abstract}
Organizational Commitment is one of important factor which needs to be considered by organization in order to increase all the employees productivity. Several things that can sustain employees Organizational Commitment are Organizational Climate, motivation, and also the level of Job satisfaction. This is proved by several studies done previously and showed that there is a significant effect from Job satisfaction and motivation towards Organizational Commitment. This study aimed to examine the impact of organizational climate, motivation and job satisfaction on organizational commitment. Several studies are done without including the research object with new organization which newly joint and also using Structural Equation Modelling (SEM) as an analysis method, so that the author included object research with newly joint organization and using SEM as the result analysis. The study is done towards 205 respondents with SEM data analysis method. The study's result showed Organizational Climate has a positive impact on Job satisfaction. Motivation has a positive impact on Job satisfaction. Motivation has a positive impact on Organizational Commitment and Job satisfaction has a positive impact on Organizational Commitment.
\end{abstract}

Keyword: Organizational Climate, Motivation, Job satisfaction and Organizational Commitment

\section{Introduction}

Shadur, Kienzle and Rodwell (1999) tested whether Organizational climate factors (such as the shared perception of the informal and formal policies, practices and procedures) affected employee attitudes such as job satisfaction and commitment. It was expected that there would be a negative relationship between bureaucracy and communication, however the evidence was to the contrary. In effect, they suggested that bureaucracies may not always be perceived negatively, rather they may include both "coercive and enabling elements". Hence, bureaucratic policies and practices may enhance job satisfaction and commitment, when employees can trust in the rules and procedures that are likely to be followed within the Organization (Jyoti, 2013)

According to Baron (1983), motivation is an accretion of diverse practices which effects and directs our behavior to accomplish certain particular goal. It is like a vigorous in the current environment that clearly produces and incorporates an optimistic influence on job. Board (2007) Motivation relay on a certain intrinsic and extrinsic features that are collaborated with positive results in abundantly devoted employees. Tangible incentives are functioning in growing performance for assignment that not completed earlier, to in spire as thinking smarter and support both quality and quantity to accomplish organizational goals (Jahenzeb, Rasheed, Rasheed, and Aamir, 2012)

According to Mangkunegara and Octorend (2015) In improving the organization of employee commitment, a good organization should look at the level of job satisfaction of employees. The reason why companies should look at the level of job satisfaction of the employees are more satisfied because of an employee in the work at the company where he worked, the higher the employee's desire to contribute to the full in order to increase company profit by running all over his responsibilities as an employee in the company with wholeheartedly.

Danish, Draz and Ali (2015) (Organizational Climate variables, Job satisfaction and Organizational Commitment) in education sector showed that Organizational Climate has a positive impact on Job satisfaction and Organizational Commitment. Jyoti (2013) (Organizational Climate variables, Job satisfaction and Organizational Commitment) in the study on education sector stated that Job satisfaction and Organizational Climate have an important role in raising the employees' Organizational Commitment. Khan, Ramzan and Butt (2013) (Organizational Climate variables, and Job satisfaction) on their study in Banking sector explained that Organizational Climate has a positive impact in increasing the employees' Job satisfaction. A research conducted by Ahmed (2011) (Motivation variables and Job satisfaction) in education sector showed a positive relation between Motivation and Job satisfaction so that the motivated employees found satisfied with their work. Yusoff and Alhaji (2012) (Motivation variables and Organizational Commitment) in their study showed Motivation to have a positive impact in effecting employees' Organizational Commitment. 
The previous studies about Organizational Climate, Motivation, Job satisfaction and Organizational Commitment have been done a number of times, however those studies are not researched within the same study and object used is from broadcasting sector in which have never been done. Therefore the author still sees the need to have a deeper understanding in relations to Organizational Climate, Motivation, Job satisfaction and Organizational Commitment and to be suggested as objects in the study. Based on the gap of study mentioned previously, the goal of this study is to provide explanation about the effect of Organizational Climate and Motivation towards Organizational Commitment mediated by Job satisfaction.

\section{Motivation}

\section{Literature Review}

Darmon (1974) said that Motivation is to educated employees to channel their effort towards organizational activities in which can increase their performance and grow their relation closer within the organization (Yusoff and Alhaji, 2012). According to Tyagi (1982) other important focus is the Management in motivating their employees by directly involved so that the increase of employees work performance can be seen from the relation built by the Management. Hence there will be a direct relation between level of Motivation and Management Participation (Yusoff and Alhaji, 2012). Salman, Aamir, Asif and Khan (2015) Motivation is about the ways a business can give confidence staff to give their most excellent. Motivated staff cares about the victory of the business and work better. In any organization employee motivation is the key factor for organizational presentation.

Hasibuan (2008) mentions that Motivation is a driving force provision that creates the excitement in working for someone in order for them to cooperate, work effectively, and integrates with all its resources to achieve satisfaction. Mangkunegara (2009) stated that Motivation is formed of an attitude of employees in facing the company employment situation. Motivation is a condition or energy that drives self-directed or directed employees to achieve organizational goals of the company.

\section{OrganizationalClimate}

Gilbert and Churchill (1976) stated that Organizational Climate is the working condition of the employees which are consisted of the organization and the relation with others in doing their job (Danish, Draz and Ali, 2015). According to Burke and Litwin (1992) the Organizational Climate explained the work system of each employees managed by themselves and effectively to work together on a job (Salman, Aamir, Asif and Khan, 2015). Climate is also stated by Moran and Volkwein (1992) as a relative characteristic in an organization which differentiate them from other organization, they are: a. For a member to have collective perception about their organization in relation to dimensions such as autonomy, trust, togetherness, support, recognition, innovation and justice; b. Able to produce interaction among members; c. Function as a base to elaborate the situation; d. To reflect general norms and cultural organization; e. To act like a source to form attitude (Salman, Aamir, Asif and Khan, 2015).

According to Bergsteiner (2011) Organizational Climate used to mentioned a space for an environmental effect such as psychological effect and organizational collectivity effect and depending on attitude (Danish et al., 2015).Stringer (2002) mentioned that there are five factors which effecting the Organizational Climate in an organization, such as external environment, strategy, leadership practice, organizational management, and organization history. Each factor is crucial, for someone to change the climate in an organization they have to evaluate each factors.

\section{Job satisfaction}

Bhuian and Menguc (2002) job satisfaction is the extent to which people feel positive or negative about the intrinsic or extrinsic of the work he did (Danish et al., 2015). Percin (2010) mentioned job satisfaction is a feeling or overall approach to employees in connection with their employment and aspects of work such as work arrangements, compensation, communication and working conditions with other colleagues (Danish et al., 2015). Singh (1990) pointed out that Job Satisfaction is a part of life satisfaction, the nature of one's environment off the job. Similarly, a job is an important part of life it influences one's general life satisfaction as an effective reaction and feelings (khan, Ramzan and Butt, 2013).

Umar (2008) suggested that job satisfaction is a feeling and an assessment on someone's work, especially regarding working conditions, in relation to whether the work is able to meet the expectations, needs, and intention. Handoko (2007) stated that job satisfaction is an emotional state which is pleasant or unpleasant on how the employees view their job.Hasibuan (2008) stated that job satisfaction is an emotional attitude of fun and loved their job. This attitude is reflected by morale, discipline, and work performance. 


\section{Organizational Commitment}

Tsai and Huang (2008) stated that Organizational Commitment is the relation of individual feelings with their job and also its organization. Organizational Commitment in general is defined as the employees awareness in an association with the organization accordingly (Danish et al., 2015). Meanwhile, according to Weihui and Zhao (2011) Organizational Commitment is a comparison of individual empathy power with an association in a certain organization (Danish et al., 2015). Mathis and Jackson (2006) organizational commitment is the extent to which employees believe and accept organizational goals, as well as the desire to stay with or leave a company ultimately reflected in absenteeism and employee turnover figures. Griffin (2005) organizational commitment is an attitude that reflects the extent to which an individual knows and tied to the organization. An individual who has committed is likely to see himself as a true member of the organization (Sriekaningsih and Setyadi, 2015)

Meyer and Allen (1997) defined Organizational Commitment as a psychological condition where an individual has the involvement in an organization and the intention to with the organization. 1. Affective Commitment defined as an employeesintention to stay emotionally to be identified with and involve in the organization. An individual, who has experienced a higher Affective Commitment, has more possibility and more willing to stay with each organization because they want to. If an employee does not have a collective ownership to the organization then they tend to have less intention to be related emotionally with the organization; 2. Continuity Commitment is defined as the awareness or benefit recognition of the employees to stay with the organization by comparing cost expended if leaving the organization. If the employee feels that the cost of leaving the organization is far more costly compare to stay with the organization, then certain employee will plan to stay instead of leaving the organization; 3. Normative Commitment is defined as a consequence of employees feeling with the obligation to say with the organization based on personal norms and organization values. The decision to stay or leave is based on individual believes of rights and moral thing to do. If an employee feels that they have to be loyal towards each organization, then they have to stay as members of the said organization. Typically, employees will see Affective Commitment higher than Normative Commitment, however still lower than Continuity Commitment (Yuen, Kee and Teck, 2011).

\section{Hypothesis Development}

Job satisfaction is determined by Organizational Climate, Work Stress, Age, and Gender have a significant impact on the level of Job satisfaction. Study done by Khan et al. (2013) showed Organizational Climate has a significant impact on the level of Job satisfaction. Jyoti (2013) stated that Job satisfaction and Organizational Climate have important roles in maintain employees by increasing their commitment with the organization. From this study it is showed that there is a significant effect between Organizational Climate towards Job satisfaction for all the professors in the India's universities. Danish et al. (2015) showed that Organizational Climate have a big enough impact towards Job satisfaction. From the analysis above, the author proposed the hypothesis:

\section{$\mathrm{H}_{1}$ : A good Organizational Climate can increase Job satisfaction}

Khalid et al. (2011) conducted this study to test the impact of rewards and motivation towards Job satisfaction between the Public Water Utility Organization and a Private one in Malaysia where it showed that Job satisfaction has a positive result which significantly influence by employees motivation. Ahmed (2011) stated that there are three aspects of motivation or Job satisfaction those are Compensation, Recognition and Work Environment. The findings of this study decided the positive and significant relation between Work Environment, Recognition and Compensation towards Motivation. Further, employees who are more motivated found to be more satisfied with their job. From the analysis above, the author propose the hypothesis:

\section{$\mathrm{H}_{2}$ : A high Motivation can increase Job satisfaction}

Yusoff and Alhaji (2012) stated that motivation has a significant result towards Organizational Commitment. Intrinsic Motivation significantly correlates with three commitment components: Affective, Continuity, and Normative. From the study conducted by Yuen et al. (2011) showed that Motivation has significantly influence Organizational Commitment of the organization's members. From the analysis above, the author propose the hypothesis:

\section{$\mathrm{H}_{3}$ : A high Job satisfaction can increase Organizational Commitment}

Rehman et al. (2013) stated the main objective from this study is to see the impact of Job satisfaction towards Organizational Commitment. Both gestures are related and dependent on each other influence, meanwhile the role of Job satisfaction in defining Organizational Commitment broadly has a significant impact influenced by Job satisfaction of the employees. Other study done by Shah, Idress, Imam, Khan and Mariyam (2014) also stated that the objective of this study is to see how the influence of a high Job satisfaction will increase the employees' Organizational Commitment in IT industry. From the analysis above, the author propose the hypothesis: 


\section{$\mathrm{H}_{4}$ : A high Job satisfaction can increase Organizational Commitment}

From the above analysis, a research model is described as follows:

Figure 1: Research Framework

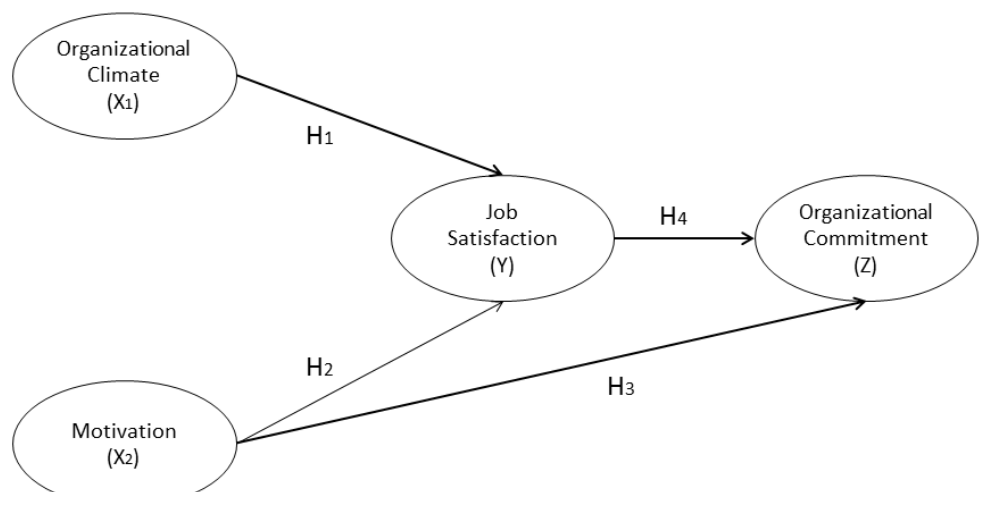

IV. Methodology

Data analysis method in this research is Structural Equation Modelling (SEM). The sample collection process is done by using Maximum Likelihood Estimation (MLE) technic, which an effective sample collection is around 150-400 samples (Sekaran, 2004). The data measurement method is using Likert scale with the interval scale of one to five. The aspects researched are Organizational Climate, Motivation, Job satisfaction and Organizational Commitment. The research is conducted on August 2016 with the research method descriptive analysis and causality model to see the connection between variables. This study is conducted towards the permanent employees in PT Indonesia Entertainment Produksi (IEP) Indonesia with total population of 205 respondents.The analysis result is then interpreted, and the last step will be concluded and then suggestion will be provided.

\section{Measurement}

In this study there are two exogen variables: Organizational Climate and Motivation, two endogen variables: Job satisfaction and Organizational Commitment, however Job satisfaction functions as moderating variables which influencing the exogen and endogen variables. The measurement of Organizational Climate variables using Litwin and Stringer (1968) dimensions; Stringer (2002), in which the dimensions are consist of Structure, Standard, Responsibility, Recognition, Support, and Commitment; Motivation variables is using Kerlinger, Fred and Elazar (1987) dimensions: Work Motive, Hope, and Incentive; Job satisfaction variables adapting the dimensions from Hasibuan (2008) which consist of pleased with the job, loving the job, Work Morale, Discipline, and Work Achievement; meanwhile the Organizational Commitment using Mayer and Allen (1997): Affective Commitment, Continuity Commitment, and Normative Commitment. Further, from the measurement dimensions included in questionnaire, validity test and reliability test will be conducted.

Validity Test is conducted with Confirmatory Factor Analysis that is by using the values of KaiserMeyer-Olkin Measure of Sampling (KMO) and Measures of Sampling Adequact (MSA). In the test, the values obtain must be bigger than 0.5 which means that analysis factor is appropriate and exact to be used, and to be further processed (Malhotra, 2004). The scale of Organizational Climate is consist of 12 questions and all of them are valid, Motivation scale is consist of 11 questions and all of them are valid, the Job satisfaction scale is consist of 10 questions and all of them are valid, and Organizational Commitment scale consist of 8 questions and all of them are valid. On the reliability test, Alpha Cronbach values is bigger than $>0.6$ which means reliable (Anindita and Hasyim, 2009), which can be said that work involvement operational, employees Work Motivation and Organizational Commitment can be concluded as reliable as instrument for data collection in this study. Next step will be data management using SEM Analysis Method. SEM is able to explicate all the complexity of variables linkages and all the direct and indirect effects from one or several variables towards other variables (Hair, 1998).

\section{Result And Discussion}

This study is focused on Job satisfaction and Organizational Commitment as the consequence of Organizational Climate and Motivation where the result showed that there are four hypothesises proposed and all data collected support the hypothesises or all hypothesises are accepted, as the SEM Testing conducted, can be seen on Figure 2 as follows: 
Figure 2 Path Diagram T-Value

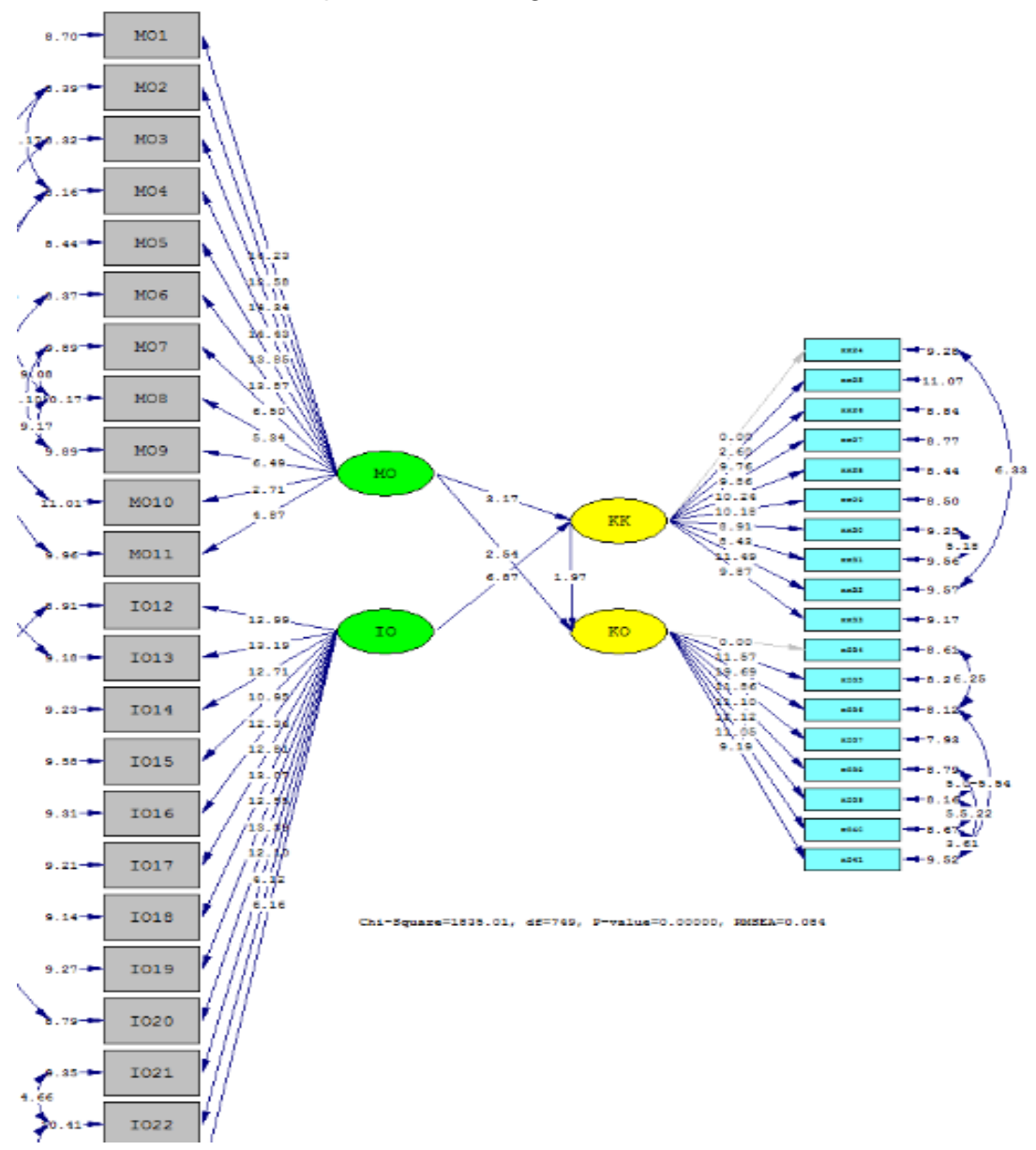

Based on Figure 2 Path Diagram T-Valueabove in which are hypothesises of this study, presented in structural equation as follows:

Table 1 Testing Hypothesis Research Model

\begin{tabular}{|c|l|c|l|}
\hline Hypothesis & \multicolumn{1}{|c|}{ Hypothesis Statement } & T-Value & \multicolumn{1}{c|}{ Details } \\
\hline $\mathrm{H}_{1}$ & $\begin{array}{l}\text { A good Organizational Climate will increase } \\
\text { Job satisfaction }\end{array}$ & 6,87 & Data support the hypothesis \\
\hline $\mathrm{H}_{2}$ & $\begin{array}{l}\text { A high Motivation can increase Job } \\
\text { satisfaction }\end{array}$ & 3,17 & Data support the hypothesis \\
\hline $\mathrm{H}_{3}$ & $\begin{array}{l}\text { A high Motivation can increase } \\
\text { Organizational Commitment }\end{array}$ & 2,54 & Data support the hypothesis \\
\hline $\mathrm{H}_{4}$ & $\begin{array}{l}\text { A high Job satisfaction can increase } \\
\text { Organizational Commitment }\end{array}$ & 1,97 & Data support the hypothesis \\
\hline
\end{tabular}

\section{Discussion}

Testing result of the first hypothesis $\left(\mathrm{H}_{1}\right)$, it is found that the analysis result is supporting the $\mathrm{H}_{1}$ hypothesis which is a good Organizational Climate will increase Job satisfaction by 6.87 . This means by a good Organizational Climate, the level of employeesJob satisfaction is also becomes higher. This result confirmed the previous studies done by Danish et al. (2015) and Jyoti (2013) where they showed the significant influence between Organizational Climate towards Job satisfaction. Therefore Organizational Climate is an important part in increasing Job satisfaction in an organization.

Testing result of the second hypothesis $\left(\mathrm{H}_{2}\right)$, it is found that the analysis result is supporting the $\mathrm{H}_{2}$ hypothesis which is a high Motivation increase Job satisfaction by 3.17. This showed that the higher the employees Motivation then the more satisfied they are in doing their job. This confirmed the previous study by Ahmed (2011) where it is found that the more motivated employees are more satisfied with their job. This is also supported by Khalid et al. (2011) that showed Job satisfaction has a significant positive impact which is influenced by employees' Motivation. Therefore a good Motivation in an organization will increase employees Job satisfaction. 
Testing result of the third hypothesis $\left(\mathrm{H}_{3}\right)$, it is found that the analysis result is supporting the $\mathrm{H}_{3}$ hypothesis that is a high Motivation can increase Organizational Commitment by 2.54 . This showed that the higher one's Motivation then the higher one's commitment to the organization. There are also studies which support this result, Yuen et al. (2011) and Yusoff and Alhaji (2012) where the result found that Motivation has a significant result on Organizational Commitment, so by maintaining the employees Motivation then the Organizational Commitment will automatically be maintained.

Testing result of the fourth hypothesis $\left(\mathrm{H}_{4}\right)$, it is found that the analysis result is supporting the $\mathrm{H}_{4}$ hypothesis which is a high Job satisfaction can increase Organizational Commitment by 1.97. This result is confirmed by the study done by Rehman et al. (2013) which stated the main goal of this study is to perceive the impact of Job satisfaction towards Organizational Commitment. The result of explained that Organizational Commitment broadly have a significant impact influenced by Job satisfaction of its employees. Hence, with the existence of a high Job satisfaction then Organizational Commitment also will be high.

Even it is not directly researched, Organizational Climate also showed a positive impact towards Organizational Commitment eventhough it is possible to happen when there is Job satisfaction from its employees. Hence, the result showed that within PT IEP Organizational Commitment is effected directly by Motivation and Job satisfaction while Organizational Climate have indirect effect.

\section{Managerial Implication}

Within an organization, maintaining employees commitment is an important thing that have to be preserved in order to have a good organizational environment. With a high commitment from its employees then the expected result by organization is better. This study is discussing factors effecting Organizational Commitment in PT IEP Indonesia, which are Organizational Climate and Motivation moderated by Job satisfaction. Managerial implication suggested is to develop a new standard operating procedure, in which can be used in a new organization. Standard operating procedure (SOP) is an important thing in executing the whole stages within PT IEP. However, because all the employees of PT IEP come from different organization, one with pre-existing SOP or active work pattern, the new one can cause the entire process to return uniformly in the work implementation so that missed coordination and missed communication that are not possible in the process of working. As an early step, PT IEP has to identify the complete existing work function and analyze the difference so that from the identification process, recommendations are provide in deciding the new SOP. After the result is identified and conclusion is shaped, the organization needs to socialized them to the whole employees so that all policies made can be known and execute by the employees. After the process ended, evaluation phase of the SOP used is also important so that the organization can still see the possible gaps created and can hamper the working activities.

To reach the same commitment among employees, organization needs engagement activities so that all employees can build a better communications than before. The existing impact from merging the organization can pose unfavourable conditions within the organization, which will create a gap between fellow leaders and even employees. This activity executed to increase Motivation and to maintain Organizational Climate in PT IEP for the better with the purpose of refreshment of the whole employees, which will affect theemployees feelings. The early stage that needs to execute is to identify problems within each unit so that organization can develop a matching program according to the current need of the organization. Then with the management create the whole planning starting from activity concept and the actual implementation of the activity and the budget needed for the execution. The final step will be to do an evaluation or review from this activity, with the purpose of seeing how major is the changes happened in each unit also the climate within PT IEP. With this plan, it is expected that the organization can provide a better changes also to maintain the employees Organizational Commitment.

\section{Conclusion}

\section{Conclusion}

The results concluded from this study are: first, a good Organizational Climate will improve job satisfaction. Second, high Motivation can increase Job satisfaction. Third, Motivation can increase the Organizational Commitment. Fourth, Job satisfaction can increase the Organizational Commitment. These results indicate that the entire results of the hypothesis in this study accepted.

\section{Limitations}

Limitations of the study refer to some weaknesses in this study. Some of the limitations found in this study are that the research was only done in the broadcasting area especially those just joining the subject of this study, is only done on the permanent employees of PT IEP. In addition, the limitations of the variables examined in this study only discuss the extent of organizational climate, motivation, job satisfaction and organizational commitment. Inconsistencies of respondents in answering the list of questions (questionnaire) 
and working conditions that make respondents are not quite comfortable when answering the list of questions (questionnaire) submitted to them is also consider as a limitation in this study.

\section{Suggestion for Further Study}

This research is still very limited because it only discussed the Organizational Commitment and Job satisfaction influenced by Organizational Climate also Motivation so that for the development of further study is recommended to include other variables such as Employee Engagement, Leadership Style, Work Life Balance, Compensation, Competition, Career Development, Work Stress, and Work Discipline. For the next study, it is hoped that it can continue on the other services company such as print/online media, Non-Governmental Organization (NGO), etc. so that the results acquire can be more objective and represent with broader coverage.

\section{References}

[1]. Agyemang, Colins Badu.,\& Ofei, Samuel Batchison. (2013). Employee Work Engagement and Organizational Commitment : A Comparative Study of Private and Public Sector Organizations In Ghana. European Journal of Business and Innovation Reasearch, Vol.1 No.4, pp.20-33.

[2]. Ahmed, Ishfaq. (2011). Relationship between Motivastion and Job Satisfaction : A Study of Higher Educational Institutions. Journal of Economics and Behavioral Studies, Vol.3 No.2, pp 94-100.

[3]. Alipour, Farhad.,\& Monfared, Masumeh Kamaee. (2015). Examining the relationship between Job Stress and Organizational Commitment Among Nurses of Hospitals. Patient safety \& Quality Improvement Journal, Vol.3 No.4.

[4]. Arikunto, S. (2010).Prosedur Penelitian (Suatu Pendekatan Praktik). Jakarta: RinekaCipta.

[5]. Asif, Mohammad., Salman, Muhammad., Aamir, Mohammad., \& Khan, Irtafa. (2015). Impact of organizational climate and engagement on motivation level of university teachers.Oeconomics of Knowledge, Volume 7, Issue 1.

[6]. Azwar.(2003). Sikap Manusia Teori Dan Pengukurannya. Yogyakarta: PustakaPelajar.

[7]. Danish, Rizwan Qaiser., Ali, Hafiz Yasir.,\& Draz, Umar. (2015). Impact of Organizational Climate on Job Satisfaction and Organizational Commitment in Education Sector of Pakistan, American Journal of Mobile Systems, Applications and Services ,Vol. 1, No. 2, 2015, pp. 102-109.

[8]. Eskandari, Asghar.,\& Siroos, Ghanbari.(2014). Organizational Climate, Job Motivation and Organizational Citizenship Behavior at the Bu-Ali Sina university.International Journal of Management Perspective, Vol.1, No.3 pp. 1-14.

[9]. EQ, Zainal Mustafa \& Toni Wijaya.(2012). Panduan Teknik Statistik SEM \& PLS dengan SPSS AMOS.Cahaya Atma Pustaka : Yogyakarta. B

[10]. Fornell, C., \& Larcker, D. (1981).Evaluating Structural Equation Models with Unobservable Variable and Measurement Error, Journal of Marketing Research, 18, 39 - 50.

[11]. Gayatri, Titan Erwiniya. (2011). Analisis motivasi, kemampuan kerja dan kinerja pegawai pusat pengelolaan komplek gelora bung karno.Universitas Indonesia.Thesis.

[12]. Gulbahar.,Amjad, Ali Ch., Gulam, Muhammad Kundi., Qamar, AffaqQureshi., \& Robina, Akhtar. (2014). Relationship Between Work-Life Balance \& Organizational Commitment. Research on Humanities and Social Sciences, Vol.4 No.5.

[13]. Hair., Anderson., Tatham., \& Black. (2008). Multivariate.Data Analysis Fifth Edition USA.Prentice Hall International Inc.

[14]. Hasibuan, Malayu S. P. (2008). Manajemen Sumber Daya Manusia. Jakarta: PT.BumiAksara.

[15]. Handoko, Hani T. (2007). Mengukur Kepuasan Kerja. Jakarta:Erlangga

[16]. Hung-Jen, Lo., Chun-Hung, Lo., Tung-Hsing, Lin., \& Peng-Fei, Tu. (2014). The Mediator Effect Of Career Development Between Personality Traits and Organizational Commitment : The Example of Sport Communication Technology Talents. The Turkish Online Journal of Educational Technology, volume 13 issue 4.

[17]. Iqbal, Muhammad.,\& Waseem, Muhammad Adnan. (2012). Impact of Job Stress on Job Satisfaction Among Air traffic Controllers of Civil Aviation Authority: An empirical study of Pakistan. International Journal of Human Resources Studies, Vol.2 No.2.

[18]. Jannah, Noraliyatun. (2011). Hubungan struktur empowerment dengan iklim organisasi perawat pelaksana di RSU Bhakti Yudha depok jawa barat.Universitas Indonesia.Thesis.

[19]. Jyoti, Jeevan. (2013). Impact of Organizational Climate on Job Satisfaction, Job Commitment and Intention to Leave: An Empirical Model.Journal of Business Theory and Practice, Vol. 1, No. 1.

[20]. Khalid, Khalizani.,Salim, Hanisah Mat., \& Siew-Phaik, Loke. The Impact of Rewards and Motivation on Job Satisfaction in Water Utility Industry.International Conference on Financial Management and Economics.IPEDR vol.11.

[21]. Khan, Anum.,Ramzan, Muhammad., \& Butt, Muhammad Saqib. (2013). Is Job Satisfaction of Islamic Banks Operational Staff Determined Through Organizaional Climate, Occupational Stress, Age and Gender.Journal of Business Studies Quarterly. Volume 4, Number 3 .

[22]. Malhotra, N. K. (2004). Riset Pemasaran: PendekatanTerapan. Jakarta: Indeks Kelompok Gramedia.

[23]. Mangkunegara, Anwar Prabu. (2009). Sumber Daya Manusia perusahaan. Remaja Rosda karya: Bandung.

[24]. Mangkunegara, Anwar Prabu.,Octorend, Tinton Rumbungan. (2015). Effect of Work Dicipline, Work Motivation and Job Satisfaction on Employee Organizational Commitment in The Company (Case Study in PT.DADA Indonesia). Universal Journal Of Management, 318-328.

[25]. Rehman, Khalid., Rehman, Zia Ur., Saif, Naveed., Khan, Abdul Sattar., Nawaz, Allah., \& Rehman, Shafiq Ur. (2013). Impacts of Job Satisfaction on Organizational Commitment: A Theoretical Model for Academicians in HEI of Developing Countries like Pakistan. International Journal of Academic Research in Accounting, Finance and Management Sciences, Vol. 3, No.1, January 2013, pp. 80-89.

[26]. Rizal, Muhamad.,Idrus, M Syafiie\&Jumahir\&Mintarti, Rahayu. (2014). Effect of Compentation on Motivation, Organizational Commitment and Employee Performance (Studies at Local Revenue Management in Kendari City).International Journal of Business and Management Invention, Volume. 3 Issue. 2, pp. 64-79.

[27]. Salisu, Jamilu B.,Chinyio, Ezekiel \& Suresh, Subashini. (2015). The Impact of Compensation on the Job Satisfaction of Public Sector Construction Workers of Jigawa state of Nigeria. The Business and Management Review, Vol. 6 No. 4.

[28]. Salman, Muhammad.,Aamir, Mohammad.,Asif, Mohammad., \& Khan, Irtafa. (2015). Impact of organizational climate and engagement on motivation level of university teachers.Oeconomics of Knowledge, Volume 7, Issue 1.

[29]. Sarwar, Aisha.,Mumtaz, Mehwiz., Batool, Zillae., \&Ikram, Sundus. (2015). Impact of Leadership Styles on Job Satisfaction and Organizational Commitment. International Review of Management and Business Review, Vol .4 Issue. 3. 
[30]. Shah, Faisal Tehseen., Idrees, Fahmeed., Imam, abeer \& Khan, Tahir Aziz. (2014). Impact of Job Satisfaction on Organizational Commitment in IT Sector Employees of Pakistan.Journal of Applied Environmental and Biological Sciences, 4(8)190-197, 2014

[31]. Sriekaningsih, Ana.,\& Setyadi, Djoko. (2015). The Effect Competence and Motivation and Cultural Organization Towards Organizational Commitment and Performance on State University Lecturers in East Kalimantan Indonesia. European Journal of Business and Management, Vol.7 No.17.

[32]. Stringer, Robert. (2002). Leadership and Organizational Climate.Prentice Hall. New Jersey.

[33]. Sugiyono. (2004). Metode Penelitian Bisnis. Cetakan Kedua. Bandung:CV Alfabeta.

[34]. Umar, H. (2008). Metode Penelitian Untuk Skripsi Dan Tesis Bisnis. Edisi Kedua. Jakarta: PT. Raja Grafindo Persada.

[35]. Vokonjanski, Jelena,.\& Nikolic, Milan. (2013). Organizational Culture and Job Satisfaction - The Effects Of Company's Ownership Structure.Journal of Engineering management and Comptetitiveness, Vol.3 No.2, 41-49.

[36]. Yuen, Onn Choong., \& Kee, Luen Wong \&Teck, Chai Lau.,. (2011). Intrinsic motivation and organizational commitment in the Malaysian private higher educat instituitions : An empirical Study. Journal of Arts, Science \& Commerce , E-ISSN 2229-4686 , ISSN 2231-4172.

[37]. Yusoff, Wan.,Alhaji, Idrisadamu. (2012). Does motivational factor influence organizational commitment and effectiveness? A review of literature.Journal of business management and economics, Vol 3(1). Pp 001-009

[38]. Zaini, Hisyam. (2008). Srategi pembelajaran aktif. Yogyakarta: InsanMandiri. 